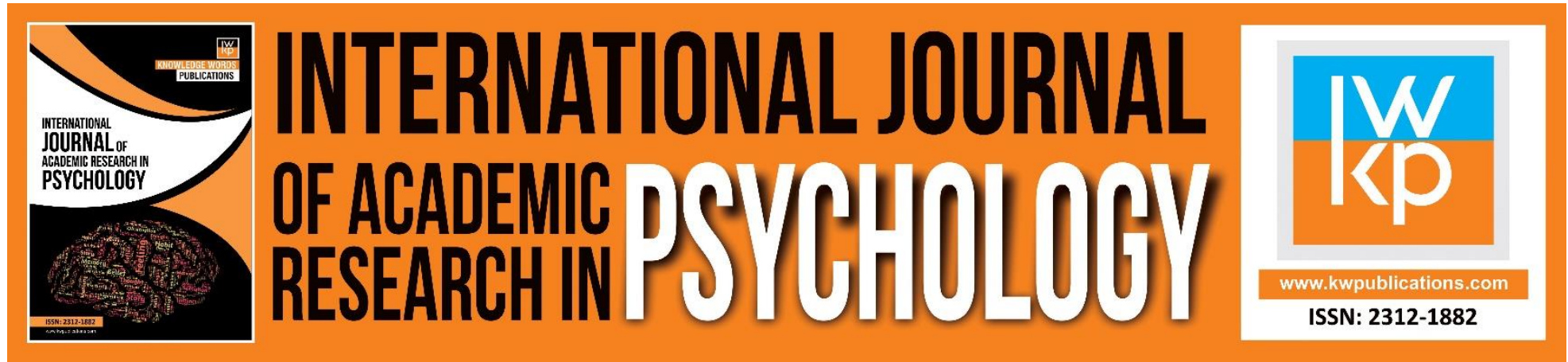

\title{
Linking Transparent Communication and Employees Openness to Change: Does Recognition Respect Matter?
}

Nomahaza Mahadi, Rina Salwani M. Tamin and Shathees Baskaran

To Link this Article: http://dx.doi.org/10.46886/IJARP/v7-i1/7164

DOI:10.46886/IJARP/v7-i1/7164

Received: 19 February 2020, Revised: 21 March 2020, Accepted: 17 April 2020

Published Online: 28 April 2020

In-Text Citation: (Mahadi et al., 2020)

To Cite this Article: Mahadi, N., Tamin, R. S. M., \& Baskaran, S. (2020). Linking Transparent Communication and Employees Openness to Change: Does Recognition Respect Matter? International Journal of Academic Research in Psychology, 7(1), 29-36.

\section{Copyright: (c) 2020 The Author(s)}

Published by Knowledge Words Publications (www.kwpublications.com)

This article is published under the Creative Commons Attribution (CC BY 4.0) license. Anyone may reproduce, distribute, translate and create derivative works of this article (for both commercial and non-commercial purposes), subject to full attribution to the original publication and authors. The full terms of this license may be seen at: $\underline{\text { http://creativecommons.org/licences/by/4.0/legalcode }}$

Vol. 7, No. 1, 2020, Pg. 29 - 36

https://kwpublications.com/journals/journaldetail/IJARP

JOURNAL HOMEPAGE

Full Terms \& Conditions of access and use can be found at https://kwpublications.com/pages/detail/publication-ethics 


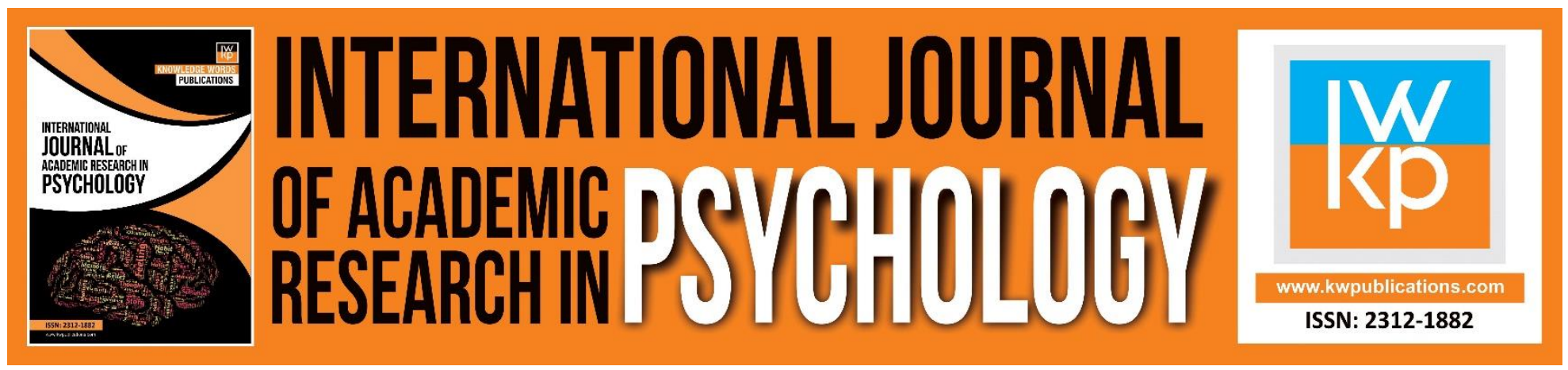

\title{
Linking Transparent Communication and Employees Openness to Change: Does Recognition Respect Matter?
}

\section{Nomahaza Mahadi ${ }^{1}$, Rina Salwani M. Tamin² and Shathees Baskaran ${ }^{3}$}

1,3 International Business School, Level 10, Menara Razak, Universiti Teknologi Malaysia, Jalan Sultan Yahya Petra, 54100 Kuala Lumpur, ${ }^{2}$ Melaka Hospital, Jalan Mufti Hj Khalil, 75400 Melaka.

Email: mahaza@ibs.utm.my

\begin{abstract}
In this current competitive business conditions, organizations are hinge on upon their leaders to inspire people who have courageous to made demand out of turmoil, explore organizations through unimaginable natural disturbance and flourish the condition with excellent human capital involvement. Leaders are also expected to reassure the changes and developments required to keep up competitive advantage. In this instance, recognition respect plays a vital part in supporting employees throughout the complex and challenging period of change implementation. Also, recognition respect is an important form of respect in workplace relationships that can bring benefits to both the individual and the organisation. However, despite respect being seen as vital for leaders in exercising influence over employees, there were little attention has been paid to investigate the concept from the viewpoint of leadership. Therefore, this paper aims to address these gaps by exploring the significant role of recognition respect in mediating the relationship between transparent communication and employee's openness to change. Our discussion highlights the importance of understanding the role of recognition respect characteristics that are involved in determining the success or failure of a change initiative.
\end{abstract}

Keywords: Recognition Respect, Organizational Change, Value-Based, Mediator, Engagement.

\section{Introduction}

Major organizational change would mean the emergence of challenges, or more precisely, barriers. The top four barriers that had been identified to impede the process of organizational change include fear of the unfamiliar or unknown, ineffective leadership, ineffective communication, as well as undue complexity (Smith, 2017). Hence, failure by leaders at any level to understand the sensitivities, fears, as well as the resistance that were occurring would create barriers or even frictions among the 
INTERNATIONAL JOURNAL OF ACADEMIC RESEARCH IN PSYCHOLOGY

Vol. 7, No. 1, 2020, E-ISSN: 2312-1882 @ 2020 KWP

executive parties (Smith, 2017). These were made worse if the changes being implemented were not communicated effectively across the whole organization. A report by McKinsey (2002) showed that the organization with a CEO who did not actively involve all the stakeholders in the change process barely reached their expected cost-saving target that were supposed to be gained through the change.

\section{Employees Openness to Change}

There were two fundamental components of openness to change, namely, a positive attitude towards the outcome of the change, and the willingness to support the proposed plans and processes during the change event (Wanberg and Banas, 2000). Employees who were opened to change look forward to the changes in their work processes, and believed that the proposed changes would have a positive effect and were for the betterment of the organization, as well as themselves as employees. These constituted the employees' behavioural intention to support the change, and, consistent with the Theory of Planned Behaviour (Azjen, 1991) the intention to perform a particular behaviour will guide subsequent behaviours (LaMorte, 2019). Whilst openness could also be a personality trait characterised by being insightful, having a wide range of interest, as well as being imaginative (Digman, 1990), the researcher in this context regarded openness to change as a state which was specific to a change related event in an organization. It reflected the employees' viewpoint, appraisal, as well as experience of the change event.

Among the differing employees' responses to change initiatives that had been studied include openness, readiness, resistance, or even cynicism towards the change initiatives (Bouckenooghe, 2010). Nielsen and Randall (2013) concluded that employees' presumptions, mindsets and demeanour to a large extent determined the change initiative processes and outcomes. Employees' openness to change had also been identified as the most important factor in determining the outcome of a change initiative, whilst the lack thereof was a predictable sign of failure of a planned change initiative (Miller, Johnson and Grau, 1994). Openness to change was also "the most important element of organizational culture that leaders should look to build" (Erturk, 2008, p.463).

\section{Recognition Respect}

Recognition respect was regarded as acting in an ethical, unbiased, trustworthy and dignified manner (Clarke, 2011). In addition, workplace surveys had consistently demonstrated respect as the most prominent feature of what constituted good leaders or effective leadership (Bernthal, Rioux, and Wellins, 1999; Bernthal and Wellins, 2005; Charlesworth, Cook, and Crozier, 2003). Respect had also been shown to be associated with increased employees' physical and mental health in the workplace, as well as heightened individual's sense of well-being and self-esteem (Huo, Binning and Molina, 2010; Smith, Tyler and Huo, 2003). It had also been demonstrated to be associated with job satisfaction, employees' organizational commitment, as well as employees' citizenship behaviour (Faulkner and Laschinger, 2008; Sleebos, Ellemers and De Gilder, 2006).

Researches in the area of interpersonal relationships had suggested the significance of mutuality in enhancing social ties, as well as self-validation and self-worth (Genero, Miller, Surrey and Baldwin, 1992). It was also suggested that one-sided relationships will ultimately lead to lowered self-esteem or even humiliation (Genero et. al., 1992). The study by Clarke and Mahadi (2017a) had found the 
predicting effect of mutual recognition respect towards both employees' job performance and wellbeing. They concluded that mutual recognition respect is an important form of respect in workplace relationships that can bring benefits to both the individual and the organisation (Clarke and Mahadi, 2017a, p. 163). Another study by the same authors had shown the positive association between mutual recognition respect and employees' affective commitment, as well as job satisfaction (Clarke and Mahadi, 2017b).

In addition, recognition respect suggested that people should be respected as they are humans, and was morally the correct thing to do (Fraser and Honneth, 2003). It was an unconditional, fundamental human right (Kant, 1964). As Benditt (2008, p. 488) put it, recognition respect was "having respect for persons as persons, means giving them appropriate consideration, the consideration due to persons as such, in deciding what to do." For instance, respect as an implicit dimension of leadership indicated that respect towards the leader was based upon his / her sensitivities, supportiveness, attentiveness, as well as responsiveness towards his / her followers' needs (Bass, 1985b). Respect was also highlighted as one of the key values that would facilitate stronger follower identification (Bass, 1985b). Reciprocally, the enhanced follower identification and greater emotional attachment brought about by leading with values enhanced respect towards the leader.

\section{Transparent Communication}

Transparency constituted openness, and was the opposite of secrecy (Rawlins, 2009). Transparent communication was a highly distinguished method of internal communication, and had been found to increase employee-organization relationships (Men and Stacks, 2014). It was characterized by three related, but analytically distinct elements, which were informational / substantial, participatory and accountability transparency (Balkin, 1999). Informational transparency (substantiality) constituted the disclosure of "truthful, substantial and useful information" (Rawlins, 2008, p. 6). The information provided to employees in this instance must be relevant, complete, accurate, reliable, timely and easily understood by employees. It was not the mere disclosure of abundant information that could cloud the employees' understanding regarding the direction and processes in the change initiative.

Participatory transparency required employees' "active participation in acquiring, distributing and creating knowledge" (Cotterrell, 1999, p. 419). It was about the organization involving the employees in helping to identify the information they needed, taking the time to understand the employees and what their needs were, as well as soliciting the employees' opinion before making a particular decision. The organization also asked for the employees' feedback on its quality of information, as well as providing detailed and accessible information to its employees. The accountability transparency constituted the organization's disclosure of both positive and negative information to its employees (Yue et. al, 2019). It presented more than one side of any controversial issues, as well as was open to criticism and admitted when it had made mistakes during the course of the change initiative. Studies had shown that the withholding of negative information during a change initiative could lead to increased employees' anxiety, uncertainty, distrust and insecurity (Men and Bowen, 2017), hence, this dimension of transparency was crucial in the success of an organization change initiative (Gergs and Trinczek, 2008). 
INTERNATIONAL JOURNAL OF ACADEMIC RESEARCH IN PSYCHOLOGY

Vol. 7, No. 1, 2020, E-ISSN: 2312-1882 @ 2020 KWP

\section{The Role of Recognition Respect between Transparent Communication and Employees Openness to Change}

Meanwhile, a lack of respect had been shown to lead to negative affects within group contexts (Bies, 1987). Studies by Dasborough (2006) had pointed insights as to how positive affect among followers were generated through exercising charismatic leadership. Studies had also demonstrated that charismatic leadership was positively related to employee's organizational citizenship behaviours (Deluga, 1995; Sosik, 2005). It was argued that the chief mechanism by which outstanding outcomes were brought about by charismatic leaders were through the engagement of follower's self-concepts which affect motivation (Shamir, House and Arthur, 1993). One of the ways of achieving this was to engage in the respect generating behaviours that contributed to the development of positive followers' social identity (Haslam and Ellemers, 2005).

Transparent communication during a change initiative appeared to have considerably large components of the antecedents to recognition respect, mainly the ethical character of the leader, leader candour and honesty, as well as leader fairness. Transparent communication also possessed the key components of personal engagement with employees, as well as leaders' empathy. These were postulated to have a positive relationship with recognition respect. Consequently, when employees engaged in a relationship that prospers recognition respect with their leaders during an organizational change event, they were more likely to have a positive attitude towards the outcome of the change. This would in turn lead to a greater acceptance of the change, as well as willingness to support the plans and processes associated with the change initiative. Thus, recognition respect played a key role as the mediator through the relationship between transparent communication and employees' openness to change.

\section{Proposition 1: Recognition respect mediates the positive relationship between transparent communication and employee's openness to change.}

\section{Conclusion}

Psychological outcomes of recognition respect include collective identification, group self-esteem, as well as group citizenship behaviour. Collective identity referred to an individual's sense of belonging to a group, while group citizenship behaviour referred to an individual's voluntary commitment within an organization that was not part of his contractual tasks (Clarke, 2011). The early work in this area had identified that respectful behaviours in both the leader or group authority figures, as well as group members, conveyed strong signals to the group fellow members that the member was accepted, valued, and of equal standing within the group (De Cremer, 2002; Tyler and Smith, 1999). This then greatly influenced the group members' willingness to comply with the authority figures in the group (Tyler and Smith, 1999). Scholars also posited that the acceptance and inclusion brought about by recognition respect would promote employees' self-esteem and self-worth (Smith et al., 1988). Thus, these intangible benefits would be reciprocated by employees' through heightening their openess to change towards the organization. Elsewhere, empirical studies had also shown that transparent communication affect different aspects of a change initiative, and reinforced the change initiative's purposes and values (Neill, 2018; Yue et al., 2019), as well as strengthened the understanding between the top management, executive parties and every stakeholder involved in the change initiative (Lewis, 1997). 
INTERNATIONAL JOURNAL OF ACADEMIC RESEARCH IN PSYCHOLOGY

Vol. 7, No. 1, 2020, E-ISSN: 2312-1882 @ 2020 KWP

\section{References}

Armenakis, A. A., Harris, S. G., and Mossholder, K. W. (1993). 'Creating Readiness for Organizational Change', Human Relations, 46(6), 681-703.

Ajzen, I. (1991). 'The theory of planned behavior', Organizational Behavior and Human Decision Processes, 50(2), 179-211.

Balkin, J. M. (1999). 'How mass media simulate political transparency', Journal for Cultural Research, 3(4), 393-413.

Barnard, C. I. (1938). The functions of the executive. Cambridge, MA: Harvard University Press.

Bass, B. M., and Avolio, B. J. (1993). Transformational leadership: A response to critiques. In B. Bass and B. Avolio (Eds.), Leadership: Theory and research perspectives and directions ( $p p$. 49-80). New York: Academic Press.

Bass, B. M. (1981). Stogdill's handbook of leadership: A survey of theory and research (2nd ed.). New York: The Free Press.

Bass, B. M. (1985a). 'Leadership: Good, better, best', Organizational Dynamics, 13(3), 26-40.

Benditt, T. M. (2008). 'Why Respect Matters', The Journal of Value Inquiry, 42, 487- 496.

Bernthal, P. R., and Wellins, R. (2005). United Kingdom global comparison: Leadership forecast 2005-2006: Best practices for tomorrow's global leaders. Development Dimensions International.

Bernthal, P. R., Rioux, S. M., and Wellins, R. (1999). The leadership forecast: A benchmarking study. executive summary. Development Dimensions International.

Bies, R. J. (1987). 'The predicament of injustice: The management of moral outrage', Research in Organizational Behavior, 9, 289-319.

Bouckenooghe, D. (2010). 'Positioning change recipients' attitudes toward change in the organizational change literature', The Journal of Applied Behavioral Science, 46(4), 500-531

Charlesworth, K., Cook, P., and Crozier, G. (2003). Leading change in the public sector: Making the difference. Chartered Management Institute.

Clarke, N. (2011) 'An Integrated Conceptual Model of Respect in Leadership', The Leadership Quarterly, 22(2), 316-327

Clarke, N., and Mahadi, N. (2017a). 'Mutual Recognition Respect between Leaders and Followers: Its Relationship to Follower Job Performance and Well-being', Journal of Business Ethics, 141(1), 163-178.

Clarke, N., and Mahadi, N. (2017b). 'The Significance of Mutual Recognition Respect in Mediating the Relationships between Trait Emotional Intelligence, Affective Commitment and Job Satisfaction', Personality and Individual Differences, 105, 129-134.

Cotterrell, R. (1999). 'Transparency, Mass Media, Ideology and Community', Journal for Cultural Research, 3(4), 414-426.

Dasborough, M. T. (2006). 'Cognitive asymmetry in employee reactions to leadership behaviors', The Leadership Quarterly, 17, 163-178.

De Cremer, D. (2002). 'Respect and cooperation in social dilemmas: The importance of feeling included,' Personality and Social Psychology Bulletin, 28, 1335-1341.

Deluga, R. J. (1995). 'The relationship between attributional charismatic leadership and organizational citizenship behaviour', Journal of Applied Social Psychology, 26, 1652-1669. 
INTERNATIONAL JOURNAL OF ACADEMIC RESEARCH IN PSYCHOLOGY

Vol. 7, No. 1, 2020, E-ISSN: 2312-1882 @ 2020 KWP

Digman, J. M. (1990) 'Personality structure: Emergence of the five-factor model', Annual Review of Psychology, 41, 417-440.

Ertürk, A. (2008). 'A trust-based approach to promote employees' openness to organizational change in Turkey', International Journal of Manpower, 29(5), 462-483.

Faulkner, J., and Laschinger, H. (2008). 'The effects of structural and psychological empowerment on perceived respect in acute care nurses', Journal of Nursing Management, 16, 214-221.

Fraser, N., and Honneth, A. (2003). 'Redistribution or recognition? A political-philosophical exchange.' London: Verso.

Fugate, M., Prussia, G. E., and Kinicki, A. J. (2012) 'Managing employee withdrawal during organizational change: The role of threat appraisal', Journal of Management, 38(3), 890914.

Genero, N. P., Miller, J. B., Surrey, J., and Baldwin, L. M. (1992). 'Measuring perceived mutuality in close relationships: Validation of the mutual psychological development questionnaire', Journal of Family Psychology, 6, 36-48

Gergs, H. H., and Trinczek, R. (2008). Communication as the key factors to change management: $A$ sociological perspective. In Holger Sievert, \& Daniela Bell (Eds.). Communication and leadership in the 21st century (pp. 141-156). Gutersloh: Verlag Bertelsmann Stiftung.

Glaso, L., and Einarsen, S. (2006). 'Experienced affects in leader-subordinate relationships', Scandinavian Journal of Management, 22,49-73.

Haslam, S. A., and Ellemers, N. (2005). 'Social identity in industrial and organizational psychology', International Review of Industrial and Organizational Psychology, 20, 39-118.

Honneth, A. (1995). The struggle for recognition: The moral grammar of social conflicts. Cambridge: Polity Press.

House, R. J., and Howell, J. M. (1992). 'Personality and charismatic leadership', Leadership Quarterly, 3, 81-108.

Huo, Y. J., Binning, K. R., and Molina, I. E. (2010). 'Testing an integrative model of respect: Implications for social engagement and well-being', Personality and Social Psychology Bulletin, 36, 200-212.

Kant, I. (1964) Groundwork of the Metaphysics of Morals, translated and analysed by H.J. Paton. New York: Harper.

LaMorte, W. W. (2019). Behavioural Change Models : The Theory of Planned Behaviour. Retrieved December 20, 2019, from http://sphweb.bumc.bu.edu/otlt/MPHModules/SB/BehavioralChangeTheories/BehavioralC hangeTheories3.html

McKinsey. (2002). Helping Employees Embrace Change. Retrieved October 23, 2019, from https://www.mckinsey.com/business-functions/organization/our-insights/helpingemployees-embrace-change

Men, L. R., and Bowen, S. (2017) Excellence in Internal Communication Management. New York: Business Expert Press.

Men, L. R., and Stacks, D. (2014). 'The effects of authentic leadership on strategic internal communication and employee-organization relationships', Journal of Public Relations Research, 26(4), 301-324. 
INTERNATIONAL JOURNAL OF ACADEMIC RESEARCH IN PSYCHOLOGY

Vol. 7, No. 1, 2020, E-ISSN: 2312-1882 @ 2020 KWP

Miller, V. D., Johnson, J. R., and Grau, J. (1994). 'Antecedents to Willingness to Participate in a Planned Organizational Change', Journal of Applied Communication Research, 22 (1), 59 80.

Neill, M. S. (2018). 'Change Management Communication: Barriers, Strategies and Messaging', Public Relations Journal, 12(1) https://prjournal.instituteforpr.org/wpcontent/uploads/NeillMarlene_ChangeManagement.pdf

Nielsen, K., and Randall, R. (2013). 'Opening the black box: Presenting a model for evaluating organizational-level interventions', European Journal of Work and Organizational Psychology, 22(5), 601-617.

Rawlins, B. (2008). 'Measuring the Relationship between Organizational Transparency and Employee Trust', Public Relations Journal, 2(2), 1-21.

Rawlins, B. (2009). 'Give the emperor a mirror: Toward developing a stakeholder measurement of organizational transparency', Journal of Public Relations Research, 21(1), 71-99.

Shamir, B., House, R. J., and Arthur, M. B. (1993). 'The motivational effects of charismatic leadership: A self-concept based theory', Organizational Science, 4, 577-594.

Sleebos, E., Ellemers, N., and De Gilder, D. (2006). 'The carrot and the stick: Affective commitment and acceptance anxiety as motives for discretionary group efforts by respected and disrespected group members', Personality and Social Psychology Bulletin, 32, 244-255.

Smith, H., Tyler, T. R., Huo, Y. J., Ortiz, D. J., and Lind, E. A. (1988). 'The self-relevant implications of the group-value model. Group membership, self-worth and treatment quality', Journal of Experimental Social Psychology, 34, 470-493.

Smith, C. (2017). 4 Barriers to Organizational Change. Retrieved October 24, 2019, from https://change.walkme.com/4-barriers-to-organizational-change/

Smith, H. J., Tyler, T. R., and Huo, Y. J. (2003). Interpersonal treatment, social identity and organizational behaviour. In S. A. Haslam, D. van Knippenberg, M. J. Platow, and N. Ellemers (Eds.), Social identity at work: Developing theory for organizational practice (pp. 155-171). Philadelphia: Psychology Press.

Sosik, J. J. (2005). 'The role of personal values in the charismatic leadership of corporatemanagers: A model and preliminary field study', The Leadership Quarterly, 16, 221-244.

Tyler, T. R., and Smith, H. J. (1999). Justice, social identity, and group processes. In T. R. Tyler, R. M. Kramer, \& O. P. John (Eds.), The psychology of the social self (pp. 223-2264). Mahwah, N.J.: Lawrence Erlbaum Associates, Publishers.

Wanberg, C. R., and Banas, J. T. (2000). 'Predictors and Outcomes of Openness to Changes in a Reorganizing Workplace', Journal of Applied Psychology, 85(1), 132-142

Yue, C. A., Men, L. R., and Ferguson, M. A. (2019). 'Bridging Transformational Leadership, Transparent Communication, and Employee Openness to Change: The Mediating Role of Trust', Public Relations Review, 45 (3), 1-13. 